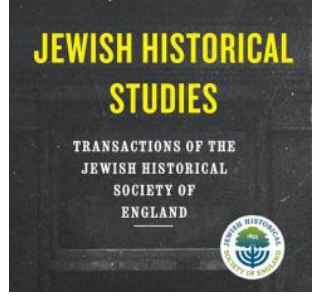

$=$ UCLPRESS

\title{
Jewish Historical Studies: Transactions of the Jewish Historical Society of England
}

\section{Israel Isidor Mattuck: Architect of Liberal Judaism}

Ellen M. Umansky ${ }^{1}$

How to cite: Umansky, E. M. 'Israel Isidor Mattuck: Architect of Liberal Judaism.' Jewish Historical Studies, 2015, 47(1): 17, pp. 245-247. DOI:

https://doi.org/10.14324/111.444.jhs.2016v47.017.

Published: 01 December 2015

\section{Peer Review:}

This article has been peer reviewed through the journal's standard double blind peer review.

\section{Copyright:}

(c) 2015, The Author(s). This is an Open Access article distributed under the terms of the Creative Commons Attribution License (CC-BY) $3.0 \mathrm{https}: / /$ creativecommons.org/licenses/by/3.0/, which permits re-use, distribution and reproduction in any medium, provided the original author and source are credited・DOI: https://doi.org/10.14324/111.444.jhs.2016v47.017

\section{Open Access:}

Jewish Historical Studies: Transactions of the Jewish Historical Society of England is a peer-reviewed open access journal. 
Israel Isidor Mattuck: Architect of Liberal Judaism, Pam Fox (London: Vallentine Mitchell, 20I4), ISBN 978-o-853-03878-8, pp. xx + 369, $£_{5}$.

This volume is the first full-scale biography of Rabbi Israel Mattuck, Senior Minister of London's Liberal Jewish Synagogue (LJS) from I9I2 until 1947 (and minister emeritus until his death in 1954), and co-founder and longtime Chairman of the Executive Committee of the World Union for Progressive Judaism (WUPJ). He also served for many years as the President of the Jewish Religious Union for the Advancement of Liberal Judaism (renamed the Union of Liberal and Progressive Synagogues in 1944), the organization out of which the Liberal Jewish movement in England emerged, and he wrote several books and religious tracts on Jewish theology, biblical thought, ethics, and Liberal Jewish belief and practice. Moreover, Mattuck created liturgies used by Liberal Jewish congregations in Great Britain and elsewhere for several decades, including his three-volume Liberal Jewish Prayer Books for Sabbaths, High Holydays and Festivals, and took an active role in communal affairs.

Representing to many the public face of Liberal Judaism, it was Mattuck who, as the American Jewish historian, Michael Meyer, notes in the book's foreword, "firmly established Liberal Judaism in England and enabled it to flourish" (p. xi). Yet, unlike Claude Montefiore and Lily Montagu, the other major figures in the early history of the Liberal Jewish movement in England, and unlike Rabbi Leo Baeck, who joined Montagu and Mattuck in leading the WUPJ after the Second World War, Mattuck has received little scholarly attention. Pam Fox's work on Mattuck, drawing on the detailed study of thousands of documents about or by Mattuck, journal articles, books, unpublished papers, interviews, and visits to archives in London and the United States, thus fills a lacuna in our understanding of the nature and growth of Progressive Judaism in Great Britain. In so doing, it underscores the significance of Mattuck not only as a leader of Liberal Judaism but also as one of the major religious figures of twentiethcentury Anglo-Jewry.

Born in Lithuania in 1883 , Mattuck (whom Fox curiously refers to by his initials "IIM" throughout the book) emigrated to the United States with his mother and four siblings in I89I, joining his father who had already settled in Boston. As Fox acknowledges, her research into Mattuck's early years in Lithuania unfortunately yielded little information. Yet she succeeds in creating a rich portrait of his life in America from the 
family's move to Worcester, Massachusetts in 1893 , through his years at Harvard and Hebrew Union College (HUC) in Cincinnati, his brief tenure as a congregational rabbi in Lincoln, Nebraska and Far Rockaway, New York, his marriage to Edna Mayer, and his "call" to England to serve as the LJS's first rabbi. Fox's labelling of the family in which Mattuck was raised as "dysfunctional" (p. 3I) seems anachronistic. However, her use of his sermons and surviving family letters produces some insight into why Mattuck did not remain close to either his parents or his seven siblings. In addition, newspapers, historical records, public addresses, and letters written by Mattuck, and Fox's correspondence with members of the Mattuck family, provide detailed information about his religious and secular education, social aspirations, financial concerns, sense of Jewish self-identity, marriage, and early career. Especially fascinating is Fox's chapter on Mattuck's experiences as a rabbinic student at HUC, his decision to leave the college a year early, procuring a full-time position as a rabbi despite the fact that he had not completed his studies, and his eventual rabbinic ordination due to surprising concessions made by the HUC faculty on his behalf. Fox fails to explain why, given the fact that Mattuck refused to fulfill the residency requirement, never completed his rabbinic thesis, and was not asked to take the final examination ordinarily taken before ordination, HUC ordained him. Nor does she explain why Mattuck was selected to deliver the valedictory address at ordination, especially in the light of the fact that the HUC president, Kaufmann Kohler, who had supervised his thesis from its inception, continually maintained that its quality was substandard. It may be that there are no extant materials to shed light on any of these matters. Yet, these "unanswered questions" (p. 8o) notwithstanding, she succeeds in revealing and critically discussing the young Mattuck's lofty personal and professional ambitions.

Perhaps the greatest scholarly contribution of this book lies in the eyeopening detail with which Fox describes Mattuck's career as the Senior Rabbi of the LJS and the impact of his religious beliefs, educational goals, liturgies, interfaith involvement, sense of social responsibility, and leadership on the development and growth of the LJS and other Progressive Jewish communities in and outside of Britain. Also important is her examination of Mattuck's opposition to the Zionist movement. She convincingly shows, for example, how his involvement in an organization called the Jewish Fellowship led to a phase in which Mattuck, despite claims to the contrary, was no longer non-Zionist but anti-Zionist. In 
his 1939 book, What Are The Jews?, he conceded that an accommodation between Zionism and Liberal Judaism might be possible were Zionism to recognize "the primacy of the Jewish religion in Jewish life" (cited p. 328). Yet even after 1948 he continued to maintain that it was neither land nor language that united the Jewish people but, rather, its faith, which could be expressed and lived anywhere. This outlook, shared by Mattuck's son-in-law and successor, Rabbi Leslie Edgar, was one of several that put England's Liberal Jewish movement out of step with the less universalistic direction taken by Progressive Judaism elsewhere and, according to Fox, consequently hindered the growth potential of the movement for the next two decades.

Although much of the focus of Fox's work is on Mattuck's career, the last third of the book focuses on his private and family life, his character and personal attributes, his failing health during the last four years of his life, his memorial service, and his legacy. These chapters, along with the book's eight pages of documents and photographs, almost all of which were preserved and made accessible to Fox by members of the family, help create a highly informative and appreciative yet critical portrayal of Israel Mattuck. Undoubtedly, it will remain the definitive book on Mattuck for many years to come.

Ellen M. Umansky 